Discourse and Communication for Sustainable Education, vol. 7, no. 1, pp. 149-160, 2016

\title{
A Retrospective Introduction to Religious Education: An Interpretive Approach
}

\author{
Robert Jackson \\ The University of Warwick, the United Kingdom
}

\begin{abstract}
The author takes a retrospective look at his book Religious Education: An Interpretive Approach, first published in 1997, and now available to readers, open access, via the European Wergeland Centre website (http://www.theewc.org/Content/Library/ResearchDevelopment/Literature/Introducing-Religious-Education-an-Interpretive-Approach). He tells a personal story of teaching, broadcasting and research, moving from the design of a methodology for studying the religions of minority groups in Britain to identifying the main concepts used for teaching about religions to children and young people in an engaging way, which relates to their own personal and social experience. The article, explains the key concept of representation - looking, for example, at how religions are often represented in ways that play down their internal diversity. Next the concept of interpretation is considered, emphasising the activity through which learners can compare and contrast the use of language by religious believers with their own nearest equivalent language uses, in trying, with sensitivity, to get as close as possible to their meanings. Finally, the process of reflexivity is explained; this gives learners an opportunity for three activities - to re-assess their understanding of their own world view (called edification in the interpretive approach), to make a distanced critique of beliefs and ideas they have studied, and to evaluate the methods that they have been using to learn about the religious meanings of others. Finally the author illustrates how the key concepts from the interpretive approach have been adapted for use in field research studies on teaching and learning about religions.
\end{abstract}

Keywords: religious education, interpretive approach, representation; interpretation, reflexivity, edification

\section{Introducing Religious Education: An Interpretive Approach}

One of the many aspects of sustainability concerns people's ability to live together in peace (Iliško, Skrinda and Mičule, 2014). Recent events, especially concerning extremist actions and religions, point up the need for people of different religious and non-religious backgrounds to understand one another's actual beliefs, values and ways of life, rather than reacting to stereotypical representations of them. This was the central theme of a book the present author wrote which was first published in 1997. This book, Religious 
Education: an Interpretive Approach (Jackson, 1997), has now been made available, open access, from the European Wergeland Centre website. The present article is a new, retrospective, introduction to the book.

The interpretive approach is one of the illustrative didactical approaches recommended in the Council of Europe publication Signposts: Policy and Practice for Teaching about Religions and Nonreligious World Views in Intercultural Education (Jackson, 2014) as a means to increase teacher and student competence for teaching and learning about religions in schools.

The book reflects the author's own work and personal and academic experience over a period of around 40 years. It is hoped that there are some ideas and principles embedded in the approach which can still be used creatively by researchers and practitioners in education. The book was originally published in 1997, with an updated reprint in 2002. In the preface to the 2002 edition, the author wrote:

The events of September 11, 2001 in New York and Washington and the riots in the North of England during the summer of 2001, and their on-going consequences, show a continuing need for children and adults to learn techniques for understanding and analysing religious and cultural material. Stereotypes and simplistic representations, so common in the popular media, need to be countered through helping people to achieve some independence in making their own interpretations and judgements about religious and cultural issues. This is an important theme running through this book. Students of religious studies and cultural studies should find the book useful, in addition to the main target audience of professionals and students working in the fields of religious education and multicultural education (Jackson, 2002).

Something along the same lines could have been written now, especially in the light of recent events involving violence in the name of religion. However, more attention would have been given to extremism, and dangers of the misuse of the Internet and social media, while nevertheless cautioning against an over-emphasis on the social aims for the study of religions (much as this dimension is very important), to the detriment of its intrinsic value, and its value as a source and stimulus for personal (including spiritual and moral) development. Something about the value of understanding world views such as secular humanism, alongside religions would also have been added, along with some discussion about the relationship between personal world views and organised world views, as the author has done in his recent book Signposts, written for the Council of Europe (Jackson, 2014).

The interpretive approach was never intended to be an all-encompassing philosophy and methodology for religious education. Fundamentally, it aimed to provide tools for understanding religious language and practices. These tools are usable by people from religious or non-religious backgrounds. Their use requires sensitivity - reflected in a wish to understand others' ways of life in their own terms, and to take their beliefs and practices seriously - and the view that gaining a closer understanding of the meanings of others might not only be inherently worthwhile, but also be relevant to researchers' or students' own spiritual, moral and social development. Although the approach emerged from the articulation of methods for understanding the religious perspectives of people from different religious backgrounds living in modern Britain, those methods, and their underlying concepts, can be applied in different ways and in different contexts. They 
have been used by researchers in other countries (e.g. Iversen, 2013; Østberg, 2002; Schihalejev, 2010); by teachers of religious education and their pupils in schools (e.g. Jackson, 1990); they shaped a series of schoolbooks in the 1990s (the Warwick RE Project, e.g. Barratt, 1994; Barratt and Price, 1996; Wayne et al., 1996); they have been used by teachers, teacher trainers and advisers in conducting action research in schools and teacher training establishments (Ipgrave, Jackson \& O'Grady, 2009); and they have been used as a reference point for an international team of researchers using qualitative and quantitative methods in collecting data from or about 14 to 16-yearolds in schools in different European countries (e.g. Jackson, 2011). The author's hope is that the ideas will continue to be used and developed creatively.

The key principles and concepts of the interpretive approach emerged as a result of a combination of practical experience as a teacher, teacher trainer, broadcaster and researcher, with reflections on reading from a variety of sources, including theology and religious studies, ethnography, social psychology, cultural history and philosophy. The approach thus draws on an eclectic mix of ideas from those who have set out to understand the beliefs and thinking of others. The interpretive approach - essentially a set of ideas, principles and concepts to be used according to need - does not attach itself to a single aim for what, in the UK, is known as 'religious education'. As indicated above, it is consistent with a set of aims regarding the study of religions as a worthwhile part of a general, liberal education, and as instrumentally important to the personal development of students, and to their lives as social beings, living in complex modern societies.

\section{Personal Background}

The author taught religious education in the city of Nottingham for five years and then moved to Coventry College of Education in 1972 as a teacher trainer, and studied for a part-time Masters degree in Philosophy at the University of Warwick at this time, which helped to shape his view of religious language (Jackson, 1982). He was then appointed to the University of Warwick in 1978, eventually setting up Warwick Religions and Education Research Unit in 1994.

1972 was the year of President Idi Amin's expulsion of people of South Asian origin from Uganda, who were given ninety days to leave the country. Many came as refugees to Britain, with a significant number settling in cities like Coventry and Leicester, where there were already communities of people with a South Asian origin. Through going into North Coventry schools to supervise students on teaching practice, the author met children and their families who introduced him to their religious communities. Thus, his first visits to a Hindu temple, a Sikh gurdwara and a mosque were not in the Indian subcontinent, but in a British city. His relationships with members of the different communities led to some informal research, and then some educational broadcasts for BBC Radio Four. Ralph Rolls, a producer in BBC Education, heard that the author was doing some work with South Asian communities and approached him about making some programmes for schools. The author conducted interviews with adults and children, wrote scripts and mini-dramas and presented a variety of programmes with Ralph Rolls and his colleague Geoffrey Marshall-Taylor. These were for older primary pupils, aged 9-11, and for secondary pupils of different ages, ranging from 11 to 16 or 17 . Some were on specific religions or religious groups, such as Hinduism and Afro-Caribbean Christianity, and there were programmes covering several religions, such as Coventry's 
Square Mile, which featured members of Hindu, Sikh, Muslim and Ukrainian Catholic Christian communities from the city. During this period, the author tried to develop a research methodology for understanding the religious language and practices of the people he had the privilege to meet.

Around this time the author met Eleanor Nesbitt, who came to a presentation he was doing about the BBC programmes that he had been making. Eleanor had been teaching in India and was well versed in Indian religions and the Hindi language. After a short time, she joined the author in some research on Hindu communities in Britain, especially in the city of Coventry. They worked together from that time until her early retirement in 2011, and their contact these days is often more through poetry than fieldwork (Eleanor Nesbitt wrote the preface to Jackson and Killingley 2015). Initially, they undertook a project on the formal nurture of children of Hindu families in classes held at temples and community centres around the country. Then, recognising that this formal activity was but a limited part of the story, they designed a project to study children from various Hindu backgrounds in the context of their families and communities, plus some time in their schools. This research built directly on the studies the author had started during a Fellowship in the study of religions at the School of Oriental and African Studies (SOAS), and his BBC work. The author and Eleanor Nesbitt focused particularly on the transmission of religious culture to young people and were fortunate to get two grants from the Leverhulme Trust to support this research (Jackson \& Nesbitt, 1993).

\section{Development of Research Methodology}

The initial methodology they designed was essentially phenomenological. They were returning to the theory and method advocated in some of the Religious Studies departments. The idea was that the researcher should set aside his or her presuppositions, and then empathise with those being studied. The author soon realised that, as a practical set of research methods, phenomenology, as understood in some Religious Studies circles, was very difficult to apply. However much you tried to set your presuppositions to one side, you could never be sure what your presuppositions were (Jackson, 1997, 7-29). Moreover, without understanding the language and terminology used by practitioners in other words, if you did not understand their meaning - how could you possibly empathise with their feelings and experiences? The author still upholds his critique of phenomenology which constitutes the first chapter of Religious Education: An Interpretive Approach. He went back to the literature to look for more effective methods and, partly going back to his experience at the School of Oriental and African Studies (SOAS) (as part of the University of London), he turned to social anthropology and other sources (Jackson, 1997, 30-48). For the author, the discovery and refinement of theory and method has always been a hermeneutical process related to direct experience through fieldwork or other forms of practice, with theory and method informing and supporting empirical observation and practice, and with the fieldwork and practice informing and suggesting modifications to theory and method.

At various times, the author has been criticised for using anthropological methods on the basis that they are inherently secularist. This is simply not the case. There have been and are various debates within social anthropology, about the colonialist legacy of 
the discipline, about its evolutionary assumptions and about its inherent anti-religiousness. As the author makes clear in Religious Education: an Interpretive Approach, he has taken a hermeneutical and non-secularist approach to social anthropology which does not mirror the discipline as a whole, but utilises some methods and insights from some particular ethnographers. He has also taken insights from theologians such as Wilfred Cantwell Smith, philosophers, including Paul Ricoeur and Jürgen Habermas, cultural critics like Edward Said, and social psychologists, such as Henri Tajfel (and later Martyn Barrett, who he had the privilege of working with at the Council of Europe). The author's work is not grounded purely in social anthropology, and certainly not in Durkheim's sociology (Jackson, 2015). With regard to ethnography, some particular features of the work of the American cultural anthropologist, Clifford Geertz (e.g. Geertz, 1988), turned out to be very useful methodologically, both in researching religious communities, and in devising didactical methods for religious education.

Essentially, Geertz saw social life as a text to be interpreted much as a literary critic might give an exposition of a novel or a poem, or how a biographer might interpret the life of a person. Geertz's technique was to collect a mass of data in the form of observations and interviews and to reflect on these in the light of insights into the religion or culture being studied, picked up from various sources. It was the interplay between the 'parts' perceived through fieldwork (for example, the personal stories of members of Hindu communities in Coventry) and the 'whole', derived provisionally from a number of sources (for example, in the case of the author's research, portrayals of 'Hinduism' in the scholarly literature), that provided insight into the nature of social reality and the key to editing a massive amount of field material into a well-crafted ethnographic story. Geertz's term for moving from a mountain of data to a finished, artistic account - akin to a good history or biography - is 'textualisation'.

The author then discovered the work of some of Geertz's critics, including the cultural historian James Clifford (Clifford, 1986), and was interested to find some of his own reservations (for example, the lack of voice given to individuals) reinforced. He did not adopt the normative post-modernist stance of Clifford, or anybody else, and he has retained a critical, liberal stance, but he did see the sense in tempering Geertz's approach with some of Clifford's observations - such as ensuring that the voices of individuals were represented in texts describing their way of life. Thus, in brief, there was a methodological and theoretical shift in the author's own work from phenomenology to a particular approach derived partly from a particular tradition within social or cultural anthropology. This was not the adoption of an inherently secularist discipline, but the utilisation of methods and insights from a particular ethnographer, combined with modified ideas from writers from a range of disciplines including theology and comparative religion, social psychology, cultural history and philosophy.

\section{The Term 'Religion'}

One of the shifts in the author's work centred on problems, raised in his and Eleanor Nesbitt's fieldwork, by the term 'Hinduism' and the term 'religion'. Although he was aware of diversity within religions, he had still thought of Hinduism as a 'whole', a complete religion. However, experience of meeting many 'Hindus' in the field put a question mark by his previous understanding of the categories 'Hinduism' and 'religion'. 
His reading in Religious Studies and Comparative Religion was of limited help in dealing with this issue - and then he came across the work of the Canadian scholar Wilfred Cantwell Smith, which complemented some key elements of Geertz's work. Since then the ideas of other colleagues in Religious Studies, notably Gavin Flood, have been helpful in clarifying the author's ideas further (Flood, 1999, discussed in Jackson, 2008).

Essentially, Smith argued that we should criticise conventional representations of religions and religion. These were shaped by Western cultural assumptions that ignored the fundamentally personal nature of religious belief in relation to accumulated tradition. In order to understand a religious position you needed to examine the interplay of the individual voice and the cumulative tradition. Smith saw close connections between all the religious traditions of the world, and this led to his formulation of a particular pluralistic theology which the author did not, personally, embrace. The relevance of Smith's work for the author was his creative, hermeneutical thinking, and this parallels the work of Geertz very closely in seeing the importance of the relationship between 'parts' and 'wholes'. The author has reservations about the unqualified language of 'wholes', which often need to be seen as provisional, and he sometimes refers to the relationship between individual cases and the wider context. The author's view is that pictures of 'whole' religions are perfectly possible, but there are competing accounts, and their boundaries are often contested (Jackson, 2008). Without this reservation, it is easy to construct stereotypical descriptions of whole religions that ignore their inner diversity and 'organic' nature.

While feeling that both Geertz and Smith provided theory that helped him to explain the complexity of his own field data, there were still questions unanswered for the author. These, largely, had to do with human power - the power to represent one branch of the tradition as the truth, for example. In looking for helpful analyses of power, the author found the work of Jürgen Habermas (1972) very helpful, but drew especially on the ideas of Palestinian cultural critic Edward Said, who had given a neo-modernist, humanistic interpretation to the radical thinking of Michel Foucault (Said, 1978). Said's post-colonialism has some faults but, nevertheless, his analysis of power relations remains a highly useful tool in interpreting social activity on the ground. Specifically, in terms of 'Hinduism' the work of Wilhelm Halbfass (1988) and, later, that of Richard King (e.g. 1999) was helpful to the author in appreciating how Westerners produced a construct of this religion, which became dominant in the academic field of comparative religion (Jackson, 1996).

\section{From Theory and Fieldwork to Didactics}

The perspectives of these various theoreticians reverberated with the material the author and Nesbitt collected through fieldwork and provided a set of tools for analysing and interpreting data. At the same time, had they not collected that data, then questions would not have been raised which guided the author towards a particular theoretical framework and set of practical methods. It was reflection on the hermeneutical relationship between questions raised through the practice of research and theory that shaped his ideas.

It was in interpreting the author's and Nesbitt's data (several years' worth of field notes, interviews with adults and children, detailed field work diaries and documents 
collected in the field) for an ethnographic report that the author began to wonder about the potential of some of these ideas for representing religious traditions to young learners, and for devising didactical methods that might be used to offer more flexible ways of interpreting religious material than those offered in comparative religion and world religions textbooks to date. This was the birth of the interpretive approach to religious education which had its germ in some writings from around the late 1980s, including Approaches to Hinduism, an introduction for teachers co-written with Sanskritist and Hinduism scholar Dermot Killingley, which combines a provisional overview of the tradition with specific case studies of different topics, drawing on ethnographic, biographical and autobiographical sources (Jackson and Killingley, 1988), and two children's books Religions through Festivals: Hinduism (which had to be titled and structured to fit the phenomenological assumptions of the series in which it appeared, but actually drew heavily on ethnographic fieldwork) (Jackson, 1989) and Listening to Hindus, written with Eleanor Nesbitt, and presenting the experience of families of various Hindu backgrounds from Coventry (Jackson \& Nesbitt, 1990). The interpretive approach is strongly reflected in the author's chapter in a book on religious education and the arts (Jackson, 1993), in an article for the British Journal of Educational Studies (Jackson, 1995), and in the experimental Warwick RE project materials for children and young people that appeared between 1994 and 1996. However, the ideas were first articulated at length in the author's 1997 book Religious Education: An Interpretive Approach (Jackson, 1997) and developed in some ways in Rethinking Religious Education and Plurality (Jackson, 2004).

\section{Key Concepts of the Interpretive Approach}

The interpretive approach includes a set of concepts, related to didactical principles and strategies, that take account of the diversity that exists within religions, allowing for the interaction of religion and culture, for change over time and for different views about the nature of religions. It can begin with examples from a particular religion, or with students' questions and concerns. This is a matter of judgement and creativity on the teacher's part; the starting point does not matter, provided the three key ideas of 'representation', 'interpretation' and 'reflexivity' are covered.

\section{Representation}

Using sources, from the history of the portrayal of religion and religions in Western literature, for example, the approach criticises the representation of 'world religions' as homogeneous belief systems. Religions are pictured more flexibly in terms of a relationship between individuals who usually belong to particular groups (such as denominations or sects) and the wider religions or 'religious traditions'. The study of individuals, in the context of the various groups with which they are associated, can inform an emerging understanding of 'religions'. Similarly, key concepts from the religions, and attempts at overviews, can be exemplified and enlivened through the consideration of particular examples of religious faith and practice.

The approach is equally critical of simplistic representations of cultures and of the relationship between religion and culture which see religions and cultures as homogeneous. The approach takes account of both the dimension of 'traditional' plurality - the 
overt diversity to be seen through the presence of different religious and ethnic groups in society - and that of 'modern' or 'postmodern' plurality, in which individuals from any background can use cultural ideas and practices from many possible sources. Descriptively speaking, the interaction of these two dimensions is reflected in the ideological and spiritual diversity to be found within religions (Jackson, 2004; Skeie, 1995).

With regard to the 'representation' of religions, the interpretive approach uses three 'levels'. The broadest level is the 'religious tradition', or 'religion'. Thus the Christian tradition encompasses all the different denominational and cultural manifestations of Christianity. It is evident that it would be impossible to have a full grasp of this. It is also clear that different insiders and outsiders would have different views about the scope of the tradition/religion. This does not matter. Each of us (teacher or student) can gradually form our own idea of the religious traditions/religions. Every time we learn something new, our previous understanding of the religion is challenged and might be modified. A discussion and analysis of key concepts fits best into this level, and can help to give a provisional framework for understanding that can be modified as more learning takes place. Another starting point could be some study of key authoritative texts. It must be emphasised that this approach does not imply religions are not 'real'; they are real, but complex, and in a sense 'organic', social phenomena.

The next level is that of the 'group'. This might be a denominational or sectarian group, or it could be an ethnic group whose members mainly practise a particular religion - or some combination of these. A project based on a family with both an Islamic and Pakistani background, or another about a local church would be informative about groups, and would also influence and inform our understanding of religions (through their interpretation of key concepts and of central texts, for example).

The third level is that of the 'individual' religious person. Every individual is unique, but each person practising a religion usually belongs to at least one religious group, which has a relationship with the wider religious tradition. It is at the level of the individual that we can appreciate best the human face of religion and hear personal stories that break stereotypes of whole religions.

The exploration of examples which illustrate the relationship between these different 'levels' can bring the study of religions to life. Students do not feel that they have to know everything, because every example studied illuminates the wider picture. Again it must be emphasised that the approach is not a post-modernist deconstruction of religions, only dealing with the beliefs and practices of individuals, but it does emphasise the 'organic' nature of religions; both their distinctiveness and internal diversity can be appreciated by looking at the relationship between individuals, groups and features of the broad religious traditions. For example, a study of biblical texts (which is worthwhile in itself), can be enhanced through looking at how particular groups use and interpret those texts, and how individuals speak of their relevance to their own lives. Using a different image, the Norwegian scholar Lars Laird Iversen uses the metaphors of liquidity, viscosity and solidity in discussing the interpretive approach (Iversen, 2013).

In terms of didactics, teachers could start with an overview of key concepts from a religion, or an extract from a religious text, or with a personal story (whether from, say, a visitor to the school or from some other source) or from the study of a group of some kind or from pupils' own previous knowledge and experience (including their own experience of religious practice or the absence of religion from their lives). 


\section{Interpretation}

Rather than asking students to leave their presuppositions to one side - as in the phenomenological approach - the interpretive approach requires a comparison and contrast between the learner's concepts and those of the 'insider'. The approach moves backwards and forwards between the 'insider's' concepts in comparison with their nearest equivalent in the student's experience. Sensitivity on the part of the student is very important and a necessary condition for empathy. The other aspect of this hermeneutical approach lies in applying the model of representation outlined above - moving to and fro between individuals in the context of their groups and the wider religious tradition. These two elements overlap in practice.

As indicated above, the approach was informed by direct experience of ethnographic fieldwork. Studies of children in Britain, from a range of different religious and cultural settings, were used as a basis for methodological reflection and as a source of material for curriculum development. Later developments of the approach used other starting points, such as key concepts or pupils' questions. The approach is flexible and can start at any point on the hermeneutical circle of learning - such as examples of religious practice, key concepts from the religion as a 'whole', or pupils' own experiences and questions.

\section{Reflexivity}

The interpretive approach does not only set out to increase knowledge. It takes the view that, in order to increase understanding, pupils need to reflect on the impact of their new learning on their previous understanding. Thus, reflexivity covers various aspects of the relationship between the experience of students and the experience of those whose way of life they are attempting to interpret. Three elements are especially important:

- learners re-assessing their understanding of their own world view (called 'edification' in the interpretive approach);

- learners making a distanced critique of material studied;

- learners developing a running critique of the interpretive process through retrospective reviews of methods of study - class discussion of methods becomes a part of the subject studied.

Approaches to teaching and learning here aim to encourage reflection and constructive criticism and require methods that give a voice to pupils, allowing them to gain insight from their peers and to be able to examine different ideas of truth held within the classroom. The 'content' of lessons is thus an interactive relationship between material provided by the teacher and the knowledge and experience of the participants. The approach aims for a conversational form of learning which can accommodate diversity and difference.

Since learning is seen as a hermeneutical process, attention needs to be given to students' reflection on their own world views in the light of their studies. Reflexive activity is intimately related to the process of interpretation. Interpretation might start from the insider's language and experience, then move to that of the student, and then shift between the two. Thus the process of understanding another's way of life is inseparable in practice from that of considering the issues and questions raised by it. 
The approach helps learners to engage with difference. Whatever differences there might appear to be between the student's world view and the way of life being studied, there may also be points of contact and overlap as well as common elements. What might appear to be entirely different on first acquaintance can end up linking with the learner's own experience in ways that challenge unquestioned assumptions.

Part of the reflexive process is to be able to engage critically with that which is studied. The management of such critical work is an important pedagogical issue, especially in teaching situations that are strongly pluralistic. Pupils need to learn how to be critical in a sensitive and constructive way. Another role for criticism as an element of reflexivity is pupils' involvement with reviewing study methods. This can reveal issues of representation and can also generate creative ideas for improvement, in the presentation of material studied to others. It can also help students to become more aware of bias in the techniques used in other forms of presentation. The key concepts from the interpretive approach were used as tools in classroom-based research in the European REDCo project (Jackson, 2011).

Teachers and teacher-researchers have adapted the interpretive approach to their own situations and needs, and some have written about their particular approaches. These include action research studies (reported in Ipgrave, Jackson and O'Grady, 2009) carried out by teachers in different school contexts, focusing on topics such as gender issues in teaching about religions (Gemma O'Dell); dialogue and conflict between teenage religious education students (Kevin O'Grady); teaching gifted and talented students (Amy Whittall); and issues concerned with assessment (Nigel Fancourt). There are also various action research studies concerned with initial teacher training and in-service training of teachers in relation to the interpretive approach (by Judith Everington, Linda Whitworth and Joyce Miller), and applications of the interpretive approach to particular challenges, such as religious extremism (Miller, 2013). Julia Ipgrave's work, in particular, shows the complementarity of the interpretive approach and approaches fostering dialogue about religious diversity between young people (eg Jackson, 2004, 109-125), and some of the work of the REDCo project focused on issues related to student-to-student dialogue about their views, facilitated and moderated by teachers (Jackson, 2014, 47-57).

\section{Conclusion}

The author hopes that this retrospective introduction to the interpretive approach might stimulate researchers and teachers to use its key concepts and principles creatively in their own work. It is hoped that the interpretive approach will help others to represent religious material sensitively, fairly and accurately, to find ways to get as close as possible to the meanings of religious believers and practitioners, and to deepen their existential response to and critical engagement with the material studied.

\section{References}

Barratt, M. (1994). Something to share. Oxford: Heinemann.

Barratt, M., \& Price, J. (1996). Meeting Christians: Book one. Oxford: Heinemann. Clifford, J. (1986). Introduction: Partial truths'. In J. Clifford and \& G. Marcus (Eds.),

Writing culture: The poetics and politics of ethnography (pp. 1-26). Berkeley: University of California Press. 
Flood, G. (1999). Beyond phenomenology: Rethinking the study of religion. London: Cassell.

Geertz, C. (1983). Local knowledge. New York: Basic Books.

Habermas, J. (1972). Knowledge and human interests. London: Heinemann.

Halbfass, W. (1988). India and Europe: An essay on understanding. Albany: State University of New York Press.

Iliško, D., Skrinda, A., \& Mičule, I. (2014). Envisioning the future: Bachelor's and Master's degree students' perspectives. Journal of Teacher Education for Sustainability, 16(2), 88-102.

Ipgrave, R. Jackson, \& K. O’Grady (Eds.), Religious education research through a community of practice: Action research and the interpretive approach. Münster: Waxmann.

Iversen, L. L. (2013) Can you be a Muslim and not believe in God? How fluid or solid are religions? Introducing viscosity to the interpretive approach. In J. Miller, K. O’Grady, \& U. McKenna (Eds.), Religion in education: Innovation in international research (pp. 167-181). Routledge: New York and London.

Jackson, R. (1982) Commitment and the teaching of world religions. In R. Jackson (Ed.), Approaching world religions (pp. 89-100). London: John Murray.

Jackson, R. (1989). Religions through festivals: Hinduism. London: Longman.

Jackson, R. (1990). Children as ethnographers. In R. Jackson, \& D. Starkings (Eds.), The Junior RE Handbook (pp. 200-207). Cheltenham: Stanley Thornes.

Jackson, R. (1995). Religious education's representation of 'Religions' and 'Cultures'. British Journal of Educational Studies, 43(3), 272-89.

Jackson, R. (1996). The Construction of "Hinduism" and its impact on religious education in England and Wales. Panorama: International Journal of Comparative Religious Education and Values, 8(1), 86-104.

Jackson, R. (1997). Religious education: an interpretive approach. Retrieved April 14, 2016, from http:/www.theewc.org/Content/Library/Research-Development/ Literature/Introducing-Religious-Education-an-Interpretive-Approach

Jackson, R. (2002). Religious Education: An interpretive approach. London: Hodder and Stoughton.

Jackson, R. (2004). Rethinking religious education and plurality: Issues in diversity and pedagogy. London: Routledge Falmer.

Jackson, R. (2011). The interpretive approach as a research tool: Inside the REDCo project. British Journal of Religious Education, 33(2), 189-208.

Jackson, R. (2008). Contextual religious education and the interpretive approach. British Journal of Religious Education, 30(1), 13-24.

Jackson, R. (2014). Signposts: Policy and practice for teaching about religions and nonreligious world views in intercultural education. Strasbourg: Council of Europe Publishing.

Jackson, R. (2015). Misrepresenting religious education's past and present in looking forward: Gearon using Kuhn's concepts of paradigm, paradigm shift and incommensurability. Journal of Beliefs and Values: Studies in Religion \& Education, 36(1), 64-78.

Jackson, R., Barratt, M., \& Everington, J. (1994.) Bridges to religions: Teacher's resource book, The Warwick RE project. Oxford: Heinemann.

Jackson, R., \& Killingley, D. (1988). Approaches to Hinduism. London: John Murray. 
Jackson, R., \& Killingley, D. (2015). Narrowboat music: Poems of life. Newcastle upon Tyne: Grevatt and Grevatt.

Jackson, R., \& Nesbitt, E. (1990). Listening to Hindus. London: Unwin Hyman.

Jackson, R., \& Nesbitt, E. (1993). Hindu children in Britain. Stoke on Trent: Trentham.

King, R. (1999). Orientalism and religion: Post-colonial theory, India and "The Mystic East”. London: Routledge.

Miller, J. (2013). Religious extremism, religious education and the interpretive approach. In J. Miller, K. O’Grady, \& U. McKenna (Eds.), Religion in education: Innovation in international research (pp. 121-133). London: Routledge.

Østberg, S. (2003). Norwegian-Pakistani adolescents: negotiating religion, gender, ethnicity and social boundaries. Young: Nordic Journal of Youth Research, 11(2), 161-181.

Said, E. (1978). Orientalism. New York: Random House

Schihalejev, O. (2010). From indifference to dialogue? Estonian young people, the school and religious diversity. Münster: Waxmann.

Skeie, G. (1995). Plurality and pluralism: A challenge for religious education. British Journal of Religious Education, 17(2), 84-91.

Wayne, E., Everington, J., Kadodwala, D., \& Nesbitt, E. (1996). Hindus. Oxford: Heinemann.

Correspondence concerning this article may be addressed to Robert Jackson, Emeritus Professor of Religions and Education, Centre for Education Studies, University of Warwick, Visiting Professor, Department of Humanities and Social Sciences Education, Stockholm University. Web: www.robertjackson.co.uk 